\title{
Determination of antithrombin activity by an amidolytic and a clotting procedure
}

\author{
A. FRIGOLA, S. ANGELONI, AND ANNA RitA CERQUETI \\ From the Laboratory of Clinical Pathology, B. Eustachio Hospital, 62027 San Severino Marche, Italy
}

SUMMARY Plasma antithrombin activity was measured using an amidolytic method (substrate Chromozym TH) and a clotting method. The mean antithrombin values found in 76 hospital outpatients were $9.4 \mu \mathrm{mol} / \mathrm{min} / \mathrm{ml}$ with the amidolytic procedure and $100.1 \%$ of antithrombin activity with the clotting procedure. The two methods correlate fairly well $(\mathrm{r}=0.85, \mathrm{P}<0.01)$ and show satisfactory reproducibility. Coefficients of variation of $5.9 \%$ and $8.8 \%$ were obtained respectively with the amidolytic and the clotting procedures. In the presence of very high levels of fibrinogen degradation products, falsely elevated antithrombin activity levels were observed with the clotting procedure but the amidolytic method is essentially unaffected. It is concluded that both methods are suitable for determining antithrombin activity but a well-standardised amidolytic procedure has advantages.

It is now generally accepted that antith rombin-III is the principal natural inhibitor of thrombin and factor Xa (Biggs et al., 1970; Yin et al., 1971). The inhibitor and thrombin or factor Xa form a stable $1: 1$ stoichiometric complex (Rosenberg and Damus, 1973); in the absence of heparin the reaction is slow and progressive, but the addition of heparin greatly accelerates the rate of formation of the complex, probably by inducing a conformational change in the inhibitor molecule (Rosenberg and Damus, 1973; Villanueva and Danishefsky, 1977). AntithrombinIII also has the property of neutralising virtually all the serine proteases of the coagulation and fibrinolytic system even if inactivation occurs at characteristically slow rates compared with that of thrombin and factor Xa (Damus et al., 1973; Highsmith and Rosenberg, 1974; Østerud et al., 1976).

From these observations it has become evident that the inhibitory action of antithrombin-III is a very important feedback mechanism in the regulation of haemostatic balance and its physiological significance is further stressed by the recognition that low levels of antithrombin-III are associated with recurrent thromboembolic disease. Congenital deficiency of antithrombin-III is a rare event, probably inherited as an autosomal dominant trait, which affects both sexes equally (Egeberg, 1965; van der

Received for publication 23 June 1978
Meer et al., 1973; Sas et al., 1974; Marciniak et al., 1974; Carvalho and Ellman, 1976; Ødegård and Abildgaard, 1977). More frequently, a low concentration of antithrombin-III is seiondary to liver disease or due to consumption as during disseminated intravascular coagulation or heparin therapy (von Kaulla and von Kaulla, 1967; Collen et al., 1977). Reduced antithrombin-III has also been reported in women using oral contraceptives (Zuck et al., 1971).

Antithrombin-III level is thus a fundamental parameter for the assessment of a 'coagulation profile'. The procedures currently employed for antithrombin-III determination are immunological or functional. Both give essentially corresponding results, but the functional assay should be preferred for two reasons: the speed of the test performance and the possibility that apparently normal antithrombin-III concentration may be associated with a low inhibitory activity (Sas et al., 1974). Until now the basis of every functional assay has been the progressive neutralisation of the clotting activity of thrombin by serum or defibrinated plasma. Recently, however, the availability of chromogenic substrates for thrombin and factor Xa has led to the development of amidolytic methods for the measurement of antithrombin activity (Blombäck et al., 1974; Ødegård et al., 1975, 1976).

The present paper compares a clotting and an amidolytic procedure in order to evaluate their suitability for determining antithrombin activity in routine laboratory work. 


\section{Material and methods}

Blood samples were collected by venepuncture with a plastic syringe, after minimal venous stasis, from 76 adult hospital outpatients (36 men and 40 women). Blood was anticoagulated by adding nine volumes to one volume of $3.8 \%$ trisodium citrate solution. Plasma obtained by centrifugation at $\mathbf{4 0 0 0}$ rpm for $\mathbf{2 0}$ minutes was used immediately or stored at $-20^{\circ} \mathrm{C}$.

A pool prepared by mixing equal amounts of fresh plasma from 17 healthy subjects was used to perform quality control studies and to prepare calibration curves.

\section{AMIDOLYTIC PROCEDURE}

The procedure employed, a modification of a previous method (Abildgaard et al., 1977), consists of adding test plasma, diluted in buffer with heparin, to a thrombin excess. Antithrombin-III plus heparin inhibit the thrombin-catalysed liberation of yellow $p$-nitroaniline ( $p$-NA) from a colourless chromogenic substrate. The reaction is stopped by adding acetic acid, and the absorbance produced by $p$-NA liberated by residual thrombin activity is read at $405 \mathrm{~nm}$.

The chromogenic substrate Tos-Gly-Pro-Arg-pNA.HCl (Chromozym TH, lot 1506503, obtained from Boehringer Mannheim) was dissolved in distilled water to $1.5 \mathrm{mmol} / \mathrm{l}$. This was stable for about six months when stored at $4^{\circ} \mathrm{C}$ in the dark.

Triethanolamine buffer, $\mathrm{pH} 8.4$, containing heparin $3 \mathrm{U} / \mathrm{ml}$ was prepared by dissolving $18.57 \mathrm{~g}$ of triethanolamine $\mathrm{HCl}$ and $11.69 \mathrm{~g}$ of $\mathrm{NaCl}$ in $800 \mathrm{ml}$ of distilled water; the pH was adjusted with $2 \mathrm{~N}$ $\mathrm{NaOH}$, and heparin (Novo Heparin, $5000 \mathrm{U} / \mathrm{ml}$, lot $32 \cdot 17)$ was added before making up to 1 litre.

Thrombin solution, $10 \mathrm{U} / \mathrm{ml}$, was obtained by reconstituting Fibrindex (Ortho Diagnostics, 50 NIH U/vial, lot ION215) with isotonic saline. Albumin stock solution was prepared by dissolving $4 \mathrm{~g}$ of bovine serum albumin (Behringwerke) in isotonic saline.

\section{ASSAY PROCEDURE}

Of the working thrombin solution, $0.1 \mathrm{ml}$ is added to $0.4 \mathrm{ml}$ of test plasma diluted 100 -fold with buffer. An interval timer is started, and, after 30 seconds, the amidolytic reaction is initiated by delivering $0.2 \mathrm{ml}$ of chromogenic substrate in the plasma-thrombin mixture. The reaction, performed at $37^{\circ} \mathrm{C}$, is stopped after exactly 30 seconds by adding $0.3 \mathrm{ml}$ of concentrated acetic acid. Absorbance at $405 \mathrm{~nm}$ is read against a blank containing $0.4 \mathrm{ml}$ of diluted plasma, $0.3 \mathrm{ml}$ of distilled water, and $0.3 \mathrm{ml}$ of concentrated acetic acid. By the same procedure is obtained the absorbance produced by thrombin alone, plasma being substituted by the albumin stock solution diluted 100 -fold with buffer.

The plasma antithrombin activity (PATA) is expressed as amount of thrombin amidolytic activity inhibited (measured by the difference between the amidolytic activity of thrombin alone and that of thrombin plus test plasma) using the following formula:

$$
\text { PATA }(\mu \mathrm{mol} / \mathrm{min} / \mathrm{ml})=\Delta \mathrm{A} \cdot \frac{\mathrm{V}_{\mathrm{t}}}{\epsilon \cdot \mathrm{V}_{\mathrm{p}} \cdot \mathrm{t}}
$$

where $\Delta \mathrm{A}$ is the difference between the absorbance of the albumin-thrombin mixture and that of plasmathrombin mixture, $V_{t}$ is the assay volume in microlitres, $V_{p}$ is the plasma added in microlitres, $\epsilon$ is the molar extinction coefficient of $p$-NA, and $t$ is the assay time in minutes. With a light pathway of $1 \mathrm{~cm}$, $V_{t}=1000 \mu l, V_{p}=4 \mu l, \epsilon=9.91 \mathrm{mmol}^{-1}$ $\mathrm{cm}^{-1}$, and $\mathrm{t}=0.5 \mathrm{~min}$, the equation reduces to:

$$
\text { PATA }(\mu \mathrm{mol} / \mathrm{min} / \mathrm{ml})=50.5 \cdot \Delta \mathrm{A}
$$

Linearity of inhibition at different antithrombinIII plasma concentrations was investigated using $1: 50,1: 75,1: 100$, and $1: 200$ dilutions of pooled plasma in buffer with heparin. $\Delta \mathrm{A}$ was plotted against the percentage of antithrombin activity, assuming as $100 \%$ that of the $1: 100$ plasma dilution. The relation obtained (Fig. 1) was a straight line which passes through the origin.

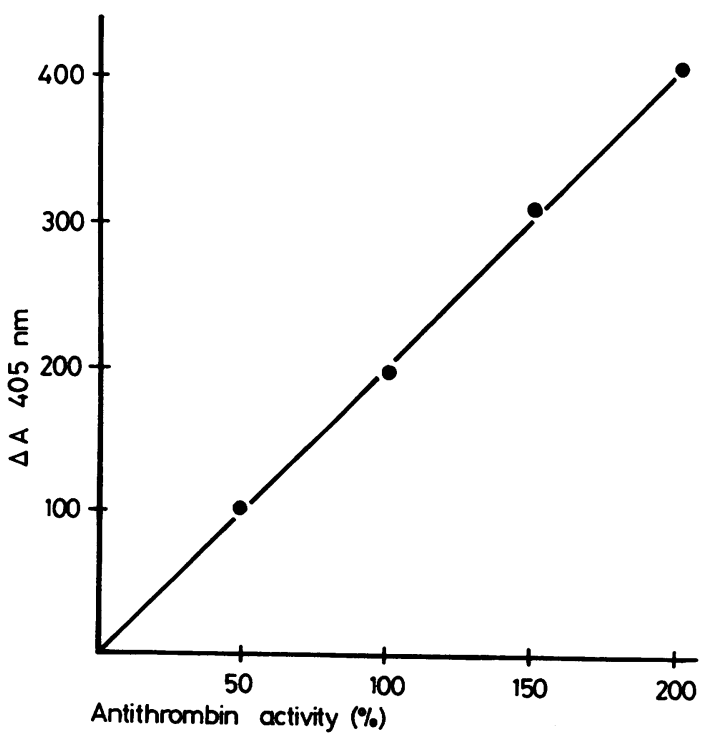

Fig. 1 Linearity of amidolytic procedure at different antithrombin concentrations expressed as activity percent. The equation of the regression line is $y=-1.8+$ $2.04 x$. 


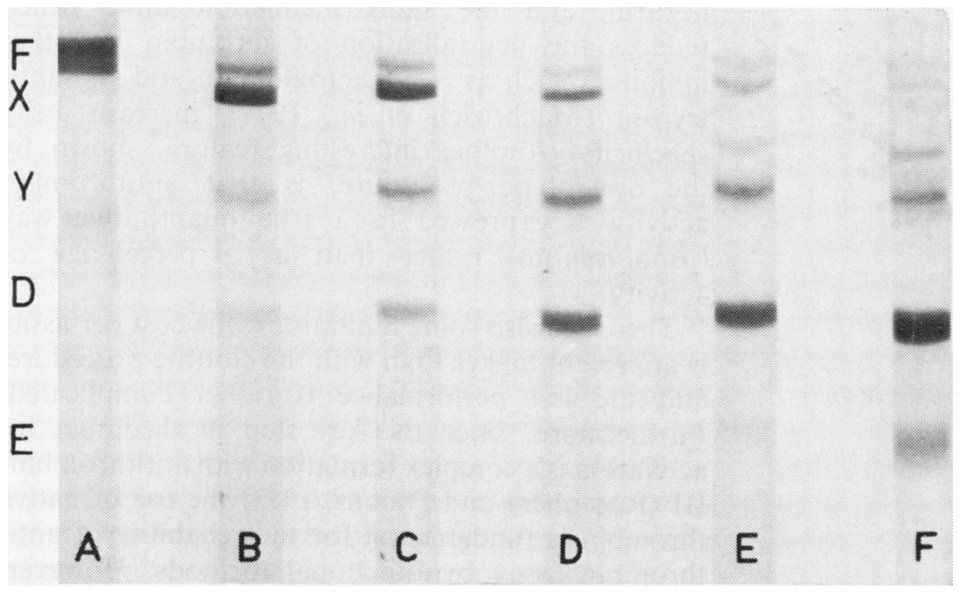

Fig. 2 SDS-polyacrylamide gel electrophoretic pattern of the plasmin digests of human fibrinogen. From A to $F$ : fibrinogen undigested and after respectively $5,15,30,45$, and 60 minutes of digestion.

CLOTTING PROCEDURE

The procedure employed was performed as previously described (Frigola, 1977) except that serum was substituted by defibrinated plasma. Defibrination was obtained by adding $0.1 \mathrm{ml}$ of Reptilase (Lepetit, Milan, lot 1123), a thrombin- like enzyme from the venom of Bothrops atrox, to $0.5 \mathrm{ml}$ of test plasma. After 10 minutes at room temperature the fibrin was removed by high-speed centrifugation, and plasma was diluted 1:5 with Tris-saline solution $(0 \cdot 154 \mathrm{M} \mathrm{NaCl}, 0.2 \mathrm{M}$ Tris buffer, $\mathrm{pH} 7 \cdot 4)$.

The defibrination step does not minimally affect the method linearity even if the precision is slightly reduced (coefficients of variation, respectively, of $2.7 \%$ using serum and of $8.8 \%$ using defibrinated plasma).

PREPARATION OF FIBRINOGEN DEGRADATION PRODUCTS (FDPS)

To study the interference of FDPs on antithrombin activity assay, an 'in vitro' plasmin digest of fibrinogen was prepared by adding Streptokinase (Streptase, Behringwerke, lot 673A) $100 \mathrm{U} / \mathrm{ml}$ final concentration to a human fibrinogen solution (Immuno, Vienna, lot $040277,10 \mathrm{mg} / \mathrm{ml})$. The reaction performed at $37^{\circ} \mathrm{C}$ was stopped at different times with $0.2 \mathrm{M} \epsilon$-aminocaproic acid (final concentration). Characterisation of FDPs was performed by sodium dodecyl sulphate-polyacrylamide gel electrophoresis on $4 \%$ gel (Fig. 2) and by densitometric analysis.

\section{Results}

The mean values for antithrombin activity found in the population under study, by the amidolytic and clotting procedures, are reported in Table 1 . Even if the two methods are based on the inhibition of
Table 1 Mean values of antithrombin activity $(n=76)$

\begin{tabular}{llc}
\hline & $\begin{array}{l}\text { Amidolytic method } \\
(\mu \operatorname{mol} / \text { min/ml })\end{array}$ & $\begin{array}{l}\text { Clotting method } \\
(\text { activity \%) }\end{array}$ \\
\hline Mean & 9.4 & 100.1 \\
$\begin{array}{l}\text { Standard deviation } \\
\begin{array}{l}\text { Standard error } \\
\text { of the mean }\end{array}\end{array}$ & 1.59 & 15.7 \\
\hline
\end{tabular}

different thrombin activities, the results obtained correlate fairly well $(r=0.85, \mathrm{P}<0.01)$; the scatter diagram and the resulting regression line are shown in Figure 3.

The precision of the amidolytic and clotting procedures was evaluated by performing respectively 27 and 24 replicate determinations on the same plasma pool; the results are reported in Table 2.

Table 2 Precision evaluation of antithrombin assay

\begin{tabular}{|c|c|c|}
\hline & $\begin{array}{l}\text { Amidolytic method } \\
(n=27) \\
(\mu \mathrm{mol} / \mathrm{min} / \mathrm{ml})\end{array}$ & $\begin{array}{l}\text { Clotting method } \\
(n=24) \\
(\text { activity } \%)\end{array}$ \\
\hline $\begin{array}{l}\text { Mean } \\
\text { Standard deviation } \\
\text { Coefficient } \\
\text { of variation }\end{array}$ & $\begin{array}{l}9.6 \\
0.5 \\
5.9\end{array}$ & $\begin{array}{r}103 \cdot 8 \\
9 \cdot 2\end{array}$ \\
\hline
\end{tabular}

The interference by FDPs with antithrombin assay was assessed by adding, in the fixed volumetric ratio of $1: 1$, the different fibrinogen digests to the same plasma pool containing $0.2 \mathrm{M} \epsilon$-aminocaproic acid in final concentration. The resulting antithrombin activity levels were determined by both procedures with reference to a control plasma to which Trissaline solution $\mathrm{pH} 7.4$ and $0.2 \mathrm{M}$ e-aminocaproic acid in final concentration were added (Table 3 ). Falsely raised antithrombin activity levels were 


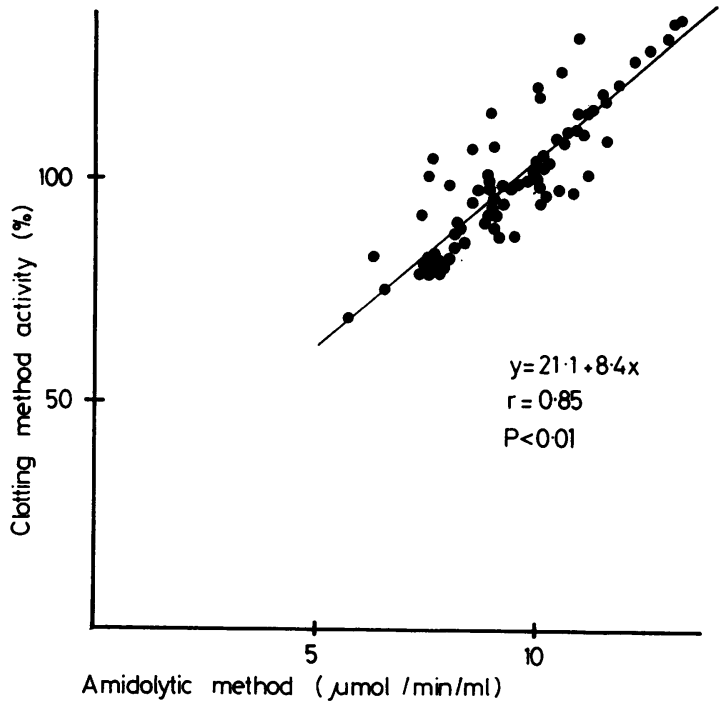

Fig. 3 Scatter diagram of correlation between antithrombin values determined by the amidolytic and the clotting procedures $(n=76)$.

Table 3 Interference of FDP on antithrombin activity determination*

\begin{tabular}{lll}
\hline & $\begin{array}{l}\text { Amidolytic method } \\
(\mu \mathrm{mol} / \mathrm{min} / \mathrm{ml})\end{array}$ & $\begin{array}{l}\text { Clotting method } \\
\text { (activity \%) }\end{array}$ \\
\hline Plasma + Tris saline & 4.74 & $48 \cdot 5$ \\
Plasma + 5 min digest & 4.46 & 53.4 \\
Plasma + 15 min digest & 4.89 & $59 \cdot 3$ \\
Plasma + 30 min digest & 4.54 & 60.6 \\
Plasma + 45 min digest & 4.94 & 55.9 \\
Plasma + 60 min digest & 4.39 & $55 \cdot 3$ \\
\hline
\end{tabular}

*The results are the mean of four determinations.

observed with the clotting procedure, particularly with 15 and 30 minutes' fibrinogen digests which contain the highest concentration of early FDPs (fragment $\mathrm{X}$ and fragment $\mathrm{Y}$ ). The amidolytic procedure was essentially insensitive to FDPs, the variation in results obtained being within the limits of the method.

\section{Discussion}

From the above results it is evident that both the methods described are suitable for antithrombin activity determination.

The amidolytic procedure shows several advantages: it is not affected by FDPs and may be performed on plasma without previous defibrination. The high plasma dilution, the use of buffer with heparin, and the short incubation time, which reduces the neutralisation of thrombin by other inhibitors such as $\alpha_{2}$-macroglobulin and $\alpha_{1}$-antitrypsin (Machovich et al., 1977), increase assay specificity. Another interesting feature, shown by the amidolytic procedure, is that antithrombin activity is expressed in a true quantitative way $(\mu \mathrm{mol} / \mathrm{min} / \mathrm{ml})$ rather than as a percentage of activity.

There are also some limitations: the cost per assay $\vec{\circ}$ is at present higher than with the clotting procedure, and the test performance is rather complicated. Furthermore, since the key step in thrombin inactivation is a complex formation with antithrombinIII (Rosenberg and Damus, 1973) the use of native thrombin is fundamental for the reliability of antithrombin assay by functional methods. However, using the amidolytic assay, it is difficult to recognise the presence of denatured thrombin in that there are structural changes in the enzyme molecule which lead to the loss of the clotting activity without any detectable modification in amidolytic activity (Gaffney et al., 1977). Thus, the clotting activity of $\vec{\varphi}$ every thrombin preparation should be checked before every amidolytic assay, mainly if thrombin has been stored after reconstitution.

The clotting method is satisfactorily precise and has the advantages of technical simplicity and relatively low cost. The principal drawback is its sensitivity to FDPs. However, it should be stressed that FDP concentrations as high as those used in our experiments (above $1000 \mu \mathrm{g} / \mathrm{ml}$ ) can be detected only in patients undergoing thrombolytic treatment for deep-vein thrombosis. At FDP levels under 100 $\mu \mathrm{g} / \mathrm{ml}$, as commonly found in acute and chronic disseminated intravascular coagulation, the accuracy of the clotting procedure method is not significantly affected.

\section{References}

Abildgaard, U., Lie, M., and Ødegård, O. R. (1977) Antithrombin (heparin cofactor) assay with "new" chromogenic substrates (S-2238 and chromozym TH). Thrombosis Research, 11, 549-553.

Biggs, R., Denson, K. W. E., Akman, N., Borrett, R., and Hadden, M. (1970). Antithrombin-III, antifactor $\mathrm{Xa}$ and heparin. British Journal of Haematology, 19, 283-305.

Blombäck, M., Blombäck, B., Olsson, P., and Svendsen, L. (1974). The assay of antithrombin using a synthetic chromogenic substrate for thrombin. Thrombosis Research, 5, 621-632.

Carvalho, A., and Ellman, L. (1976). Hereditary antithrombin-III deficiency. Effect of antithrombin-III deficiency on platelet function. American Journal of Medicine, 61, 179-183. 
Collen, D., Schetz, J., De Cock, F., Holmer, E., and Verstraete, M. (1977). Metabolism of antithrombin-III (heparin cofactor) in inan: effects of venous thrombosis and of heparin administration. European Journal of Clinical Investigation, 7, 27-35.

Damus, P. S., Hicks, M., and Rosenberg, R. D. (1973). Anticoagulant action of heparin. Nature, 246, 355-357.

Egeberg, O. (1965). Inherited antithrombin deficiency causing thrombophilia. Thrombosis et Diathesis Haemorrhagica, 13, 516-530.

Frigola, A. (1977). Standardisation of a simple method for the determination of antithrombin activity. Journal of Clinical Pathology, 30, 881-883.

Gaffney, P. J., Lord, K., Brasher, M., and Kirkwood, T. B. L. (1977). Problems in the assay of thrombin using synthetic peptides as substrates. Thrombosis Research, 10, 549-556.

Highsmith, R. F., and Rosenberg, R. D. (1974). The inhibition of human plasmin by human antithrombinheparin cofactor. Journal of Biological Chemistry, 249, 4335-4338.

von Kaulla, E., and von Kaulla, K. N. (1967). Antithrombin-III and diseases. American Journal of Clinical Pathology, 48, 69-80.

Machovich, R., Borsodi, A., Blaskó, G., and Orakzai, S. A. (1977). Inactivation of $\alpha$ - and $\beta$-thrombin by antithrombin-III, $\alpha$ 2-macroglobulin and $\alpha$ 1-proteinase inhibitor. Biochemical Journal, 167, 393-398.

Marciniak, E., Farley, C. H., and De Simone, P. (1974). Familial thrombosis due to antithrombin-III deficiency. Blood, 43, 219-231.

van der Meer, J., Stoepman-van Dalen, E. A., and Jansen, J. M. S. (1973). Antithrombin-III deficiency in a Dutch family. Journal of Clinical Pathology, 26, 532-538.

Ødegård, O. R., and Abildgaard, U. (1977). Antifactor $\mathrm{Xa}$ in thrombophilia. Studies in a family with Ar-III deficiency. Scandinavian Journal of Haematology, 18, 86-90.

Ødegård, O. R., Lie, M., and Abildgaard, U. (1975). Heparin cofactor activity measured with an amidolytic method. Thrombosis Research, 6, 287-294.

Ødegård, O. R., Lie, M., and Abildgaard, U. (1976). Antifactor Xa activity measured with amidolytic methods. Haemostasis, 5, 265-275.

Østerud, B., Miller-Andersson, M., Abildgaard, U., and Prydz, H. (1976). The effect of antithrombin-III on the activity of the coagulation factors VII, IX and X. Thrombosis and Haemostasis, 35, 295-304.

Rosenberg, R. D., and Damus, P. S. (1973). The purification and mechanism of action of human antithrombinheparin cofactor. Journal of Biological Chemistry, 248, 6490-6505.

Sas, G., Blaskó, G., Bánhegyi, D., Jákó, J., and Pálos, L. A. (1974). Abnormal antithrombin-III (antithrombin III "Budapest") as a cause of a familial thrombophilia. Thrombosis et Diathesis Haemorrhagica, 32, 105-115.

Villanueva, G. B., and Danishefsky, I. (1977). Evidence for a heparin-induced conformational change on antithrombin-III. Biochemical and Biophysical Reseurch Communications, 74, 803-809.

Yin, E. T., Wessler, S., and Stoll, P. J. (1971). Identity of plasma activated factor $\mathrm{X}$ inhibitor with antithrombinIII and heparin cofactor. Journal of Biological Chemistry, 246, 3712-3719.

Zuck, T. F., Bergin, J. J., Raymond, J. M., and Dwyre, W. R. (1971). Implications of depressed antithrombinIII activity associated with oral contraceptives. Surgery, Gynecology and Obstetrics, 133, 609-612.

Requests for reprints to: Dr A. Frigola, Laboratory of Clinical Pathology, Ospedale Regionale della Valle d'Aosta, 11100 Aosta, Italy 